\title{
Hydrogeochemical and Stream Sediment Reconnaissance of the National Uranium Resource Evaluation Program
}

\author{
January-March 1978
}

The Rocky Mountain States of New Mexico, Colorado, Wyoming, and Montana, and the State of Alaska

先

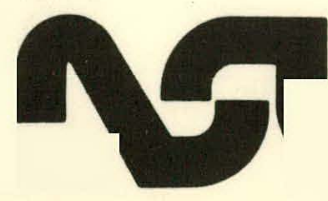




\section{DISCLAIMER}

This report was prepared as an account of work sponsored by an agency of the United States Government. Neither the United States Government nor any agency Thereof, nor any of their employees, makes any warranty, express or implied, or assumes any legal liability or responsibility for the accuracy, completeness, or usefulness of any information, apparatus, product, or process disclosed, or represents that its use would not infringe privately owned rights. Reference herein to any specific commercial product, process, or service by trade name, trademark, manufacturer, or otherwise does not necessarily constitute or imply its endorsement, recommendation, or favoring by the United States Government or any agency thereof. The views and opinions of authors expressed herein do not necessarily state or reflect those of the United States Government or any agency thereof. 


\section{DISCLAIMER}

Portions of this document may be illegible in electronic image products. Images are produced from the best available original document. 
An Affirmative Action/Equal Opportunity Employer

The four most recent reports in this unclassified series are LA-6831-PR, LA-6992-PR, LA-6993-PR, and LA-7175-PR.

This work was supported by the US Department of Energy, Division of Uranium Resources and Enrichment. Program Code B048.

This report was prepared as an aceount of work sponsored by the United by the United stales Goved as anc. Neither the United States employees, nor any of their contractors subcontructors. their employees, makes any warranty, expreas or implied, aseumes any leal liability or responsibility for the accuracy. completeness, or usefulness of any information, apparatus. product, or process dieclosed, or repreants that its use would not infringe privately ow ned rights. 
LA-7544-PR

Progress Report

Special Distribution

Issued: October 1978

\title{
Hydrogeochemical and Stream Sediment Reconnaissance of the National Uranium Resource Evaluation Program
}

\author{
January-March 1978
}

The Rocky Mountain States of New Mexico, Colorado, Wyoming, and Montana, and the State of Alaska

Thomas A. Weaver

Merle E. Bunker James M. Hansel, Jr.

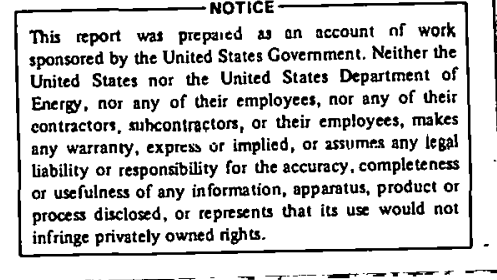

infringe privately owned rights. 


\section{PAGES ii to iv WERE INTENTIONALLY LEFT BLANK}


CONTENTS

LIST OF ILLUSTRATIONS

LIST OF TABLES vi

$\begin{array}{lll}\text { ABSTRACT } & 1\end{array}$

I. INTRODUCTION 2

II. ACTIVITIES 2

Sampling 2

Bid Invitations 2

Status 2

Sample Analysis $\quad 6$

Fluorometry 6

Plasma-Source Emission Spectrography . :7

Arc-Source Emission Spectrography $\quad 7$

Neutron Activation Analysis and Delayed-

Data Management 8

Reporting

Meetings $\quad . \quad 11$

Personnel $\quad \cdot 11$

III. ANALYTICAL PROCEDURES . 11

Uranium Determination in Water Samples by Fluorometry 11

Uranium Determination in Water Samples by DNC 14

Elemental Determinations in Water Samples by Plasma-
Source Emission Spectrography

Uranium Determination in Sediment Samples by DNC 15

Elemental Determinations in Sediment Samples by EnergyDispersive X-Ray Fluorescence

Elemental Determinations in Sediment Samples by ArcSource Emission Spectrography 15

Elemental Determinations in Sediment Samples by NAA 16

REFERENCES

APPENDIX A Hydrogeochemical and Stream Sediment Reconnaissance Data Reports Prepared by LASL for Open Filing by the US DOE, Grand Junction Office

APPENDIX B Hydrogeochemical and Stream Sediment Reconnalssance Program-Related Reports Prepared by LASL for Open Filing by the US DOE, Grand Junction Office

APPENDIX C Hydrogeochemical and Stream Sediment Reconnaissance Quarterly Progress Reports Prepared by LASL for Open Filing by the US DOE, Grand Junction Office 


\section{LIST OF ILLOSTRATIONS}

Fig. No.

1. Status of LASL HSSR reconnaissance sampling in the lower states (as of 31 March 1978).

2. Status of LASL HSSR reconnalssance sampling in Alaska (as of 31 March 1978).

3. LASL OWR pneumatic transfer system schematic.

4. Control and data acquisition/analysis system schematic for LASL DNC and NAA.

5. LASL reconnalssance report status for the lower states (as of 31 Maroh 1978).

6. LASL recunna 1ssanne roport atatuo for Alaska (ay uf 31 March 1978).

\section{LIST OF TABLES}

Table 'No.

I. Quotations Received in Response to Commercial Bid Invitations for LASL Purchase Order No. LP8-5786C. 


\author{
HYDROGEOCHEMICAL AND STREAM SEDIMENT RECONNAISSANCE \\ OF THE NATIONAL URANIUM RESOURCE EVALUATION PROGRAM
}

January-March 1978

by

Thomas A. Weaver, Merle E. Bunker, and James M. Hansel, Jr.

\begin{abstract}
The modifications to the Los Alamos Scientific Laboratory (LASL) Hydrogeochemical and Stream Sediment Reconnaissance (HSSR) program, necessary to incorporate the expansion and revision of the overall HSSR program as required by the Department of 'Energy, have been' completed. To date, approximately 57\% of the total area assigned to the LASL in the Rocky Mountain region and Alaska has been sampled and plans are well underway to sample an additional 28\% during FY 78. Contracts have been let to complete the sampling of the LASL area in the lower states and bids to sample an additional 33\% of Alaska are being evaluated. Twenty reports ( 2 in press and 18 in preparation) are presently scheduled to be open filed within six months, reporting uranium data only for 18 complete quadrangles and multielement data for 11 complete quadrangles. In addition, data releases are being prepared to open file the uranium data from portions of 13 quadrangles that are now outside the LASL reporting boundary but which had been sampled by the LASL prior to the establishment of the new boundary in October 1977. By the end of the quarter, all multielement analysis systems were operational. Water samples from 7780 locations and sediment samples from 4170 locations were analyzed for uranium. Samples from approximately 6500 locations were analyzed by one or more of the multielement methods.
\end{abstract}




\section{INTRODUCTION}

This report outlines the activities and progress of the Los Alamos Scientific Laboratory (LASL) in the Hydrogeochemical and Stream Sediment Reconnaissance (HSSR) for uranium, sponsored by the Department of Energy (DOE) and managed by the DOE Grand Junction Office (GJO), during the January-March 1978 quarter. The HSSR program, one phase of the National Uranium Resource Evaluation (NURE), is designed to identify those areas that are geochemically favorable for uranium mineralization throughout the conterminous United States and Alaska. The ultimate goals of the NURE program are to provide a comprehensive, uranium-resource assessment of the entire country and to make the resulting information available on a timely basis to the private sector so that follow-up investigations of the more favorable areas can be conducted. The LASL is now responsible for the HSSR sampling in 66 National Topographic Map Series (NTMS), 1:250 000-scale quadrangles in the Rocky Mountain region, covering New Mexico, Colorado, Wyoming, Montana, and (since October of 1977) parts of Texas, Oklahoma, Arizona, Utah, and Idaho and in 153 NTMS quadrangles in Alaska.

\section{ACTIVITIES}

The modifications to the HSSR program required by the DOE GJO in October 1977 (Morris et al, 1978) have caused the LASL to reorganize several data bases and reorder both the analytical and report writing priorities. Several reports that were in progress had to be discarded and their respective data bases broken apart because they did not conform to $2^{\circ}$ NTMS quadrangles. These reorganizations have set back the LASL HSSR effort approximately three calendar months (about five man years) during the first and second quarters of FY 78. The following sections detail the progress made during the quarter and the status of various portions of the LASL HSSR program as of March 31, 1978.

\section{Sampling}

Bid Invitations. Invitations to bid on the sampling of eight separate areas in the Rocky Mountain region were sent to 23 geochemical and geological consulting firms. The eight areas, each approximately $35000 \mathrm{~km}^{2}$, were to be sampled at a nominal density of one sample location every $10 \mathrm{~km}^{2}$ in accordance with LASL contract specification SP-4937 (dated December 6, 1977). Closing date for the acceptance of bid quotations was February 6, 1978. From the 23 bid invitations sent, the LASL received 17 quotations and 6 "no responses." The 17 quotations received are shown in Table I, with the bid for each area listed on a price-per-sample-location basis. In every case, contracts were let to the low bidder for each of the eight areas.

Invitations to bid on the sampling of four areas in Alaska, covering a total of more than $450.000 \mathrm{~km}^{2}$, were sent out and the bids have been recelved. These are presently being evaluated; when contractors have been selected and contracts signed, the bid prices for these areas will be published.

Status. The LASL reporting boundary, established by the DOE GJO in October 1977, encloses 66 NTMS quadrangles in the Rocky Mountain region. The LASL is responsible for sampling and reporting on these 66 quadrangles and all 153 NTMS quadrangles in Alaska. As of the end of the quarter, 34 of the 66 lower-state (Fig. 1) and 27 Alaskan (Fig. 2) quadrangles had been completely 
QUOTATZONS RECEIVED IN RESPONSE TO COMMERCIAL BID INVITATION FOR

LASL PURCHASE ORDER NO. LP8-5786C

Field Sampling for HSSR Program in Accordance with Specification No. SP-4937 dated 12/6/77

(Closing Date for Acceptance of Bid Quotations was 2/6/78)

\begin{tabular}{|c|c|c|c|c|c|c|c|c|}
\hline Contractor & $\begin{array}{l}\text { Roswell/ } \\
\text { Carlsbad }\end{array}$ & $\begin{array}{l}\text { Dalhart/Tucum- } \\
\text { cari/Clovis }\end{array}$ & $\begin{array}{l}\text { Gallup/ } \\
\text { Shiprock }\end{array}$ & $\begin{array}{c}\text { Grand Junction/ } \\
\text { Cortez/Moab/Vernal } \\
\end{array}$ & $\begin{array}{l}\text { Miles City/ } \\
\text { Glendive }\end{array}$ & $\begin{array}{c}\text { Forsyth/ } \\
\text { Jordan }\end{array}$ & $\begin{array}{l}\text { Lewistown/ } \\
\text { Havre }\end{array}$ & $\begin{array}{l}\text { Choteau/ } \\
\text { Cutbank }\end{array}$ \\
\hline A & 9.35 & 10.23 & 12.43 & 17.48 & 12.24 & 14.43 & 12.73 & 26.35 \\
\hline B & 10.25 & NB & 10.25 & 10.25 & 10.25 & 10.25 & 10.25 & $\mathrm{NB}$ \\
\hline c & 11.28 & 10.56 & 10.56 & 11.35 & 9.66 & 9.66 & 9.77 & 13.44 \\
\hline D & NB & NB & NB & NB & 11.85 & 10.95 & 10.85 & 10.61 \\
\hline E & 11.91 & 10.41 & 13.45 & 11.21 & 11.13 & 11.13 & 11.13 & 15.78 \\
\hline $\mathbf{F}$ & 10.22 & 11.87 & 11.63 & 10.74 & 12.52 & 12.23 & 12.87 & 13.34 \\
\hline G & 10.88 & 11.47 & 12.85 & 12.90 & NB & NB & NB & NB \\
\hline H & 12.87 & 10.92 & $\mathrm{NB}$ & NB & NB & 15.92 & NB & NB \\
\hline I & 12.37 & 12.29 & 12.49 & NB & NB & NB & NB & NB \\
\hline $\mathrm{J}$ & NB & NB & NB & NB & 10.89 & 10.89 & 10.65 & 11.91 \\
\hline $\mathrm{k}$ & 12.32 & NB & NB & NB & NB & 12.73 & NB & NB \\
\hline $\mathrm{L}$ & 13.90 & NB & $\mathrm{NB}$ & 19.90 & NB & NB & NB & NB \\
\hline M & 14.27 & NB & NB & 14.27 & NB & NB & NB & NB \\
\hline $\mathbf{N}$ & 17.00 & 10.90 & 14.50 & 18.00 & 14.95 & 15.90 & NB & NB \\
\hline 0 & 23.99 & 21.36 & 21.36 & 20.99 & 23.24 & 23.24 & 23.94 & 21.94 \\
\hline P & NB & NB & NB & NB & 21.85 & 21.83 & 21.83 & 21.83 \\
\hline Q & NB & NB & 24.99 & NB & NB & NB & NB & 23.02 \\
\hline
\end{tabular}

Notes: of the 23 bid invitations sent out, 17 responses were received with the bids shown above. The remaining six invitations brought no response. The low bid for each area is shown boxed in heavy lines and was accepted at the price-per-sample location shown. $\mathrm{NB}=$ No Bid. 


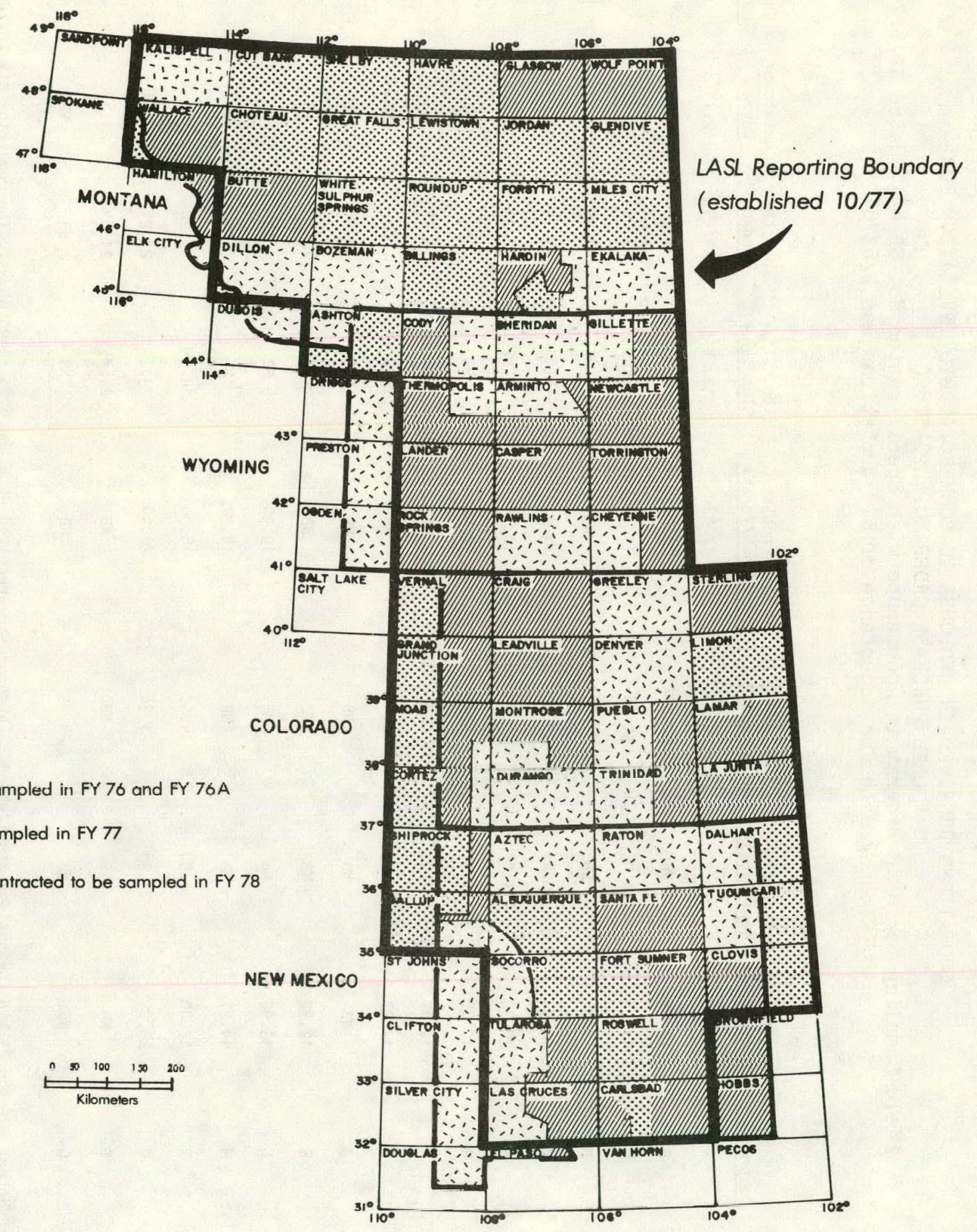

Fig. 1. Status of LASL HSSR reconnaissance sampling in the lower states (as of 31 March 1978). 


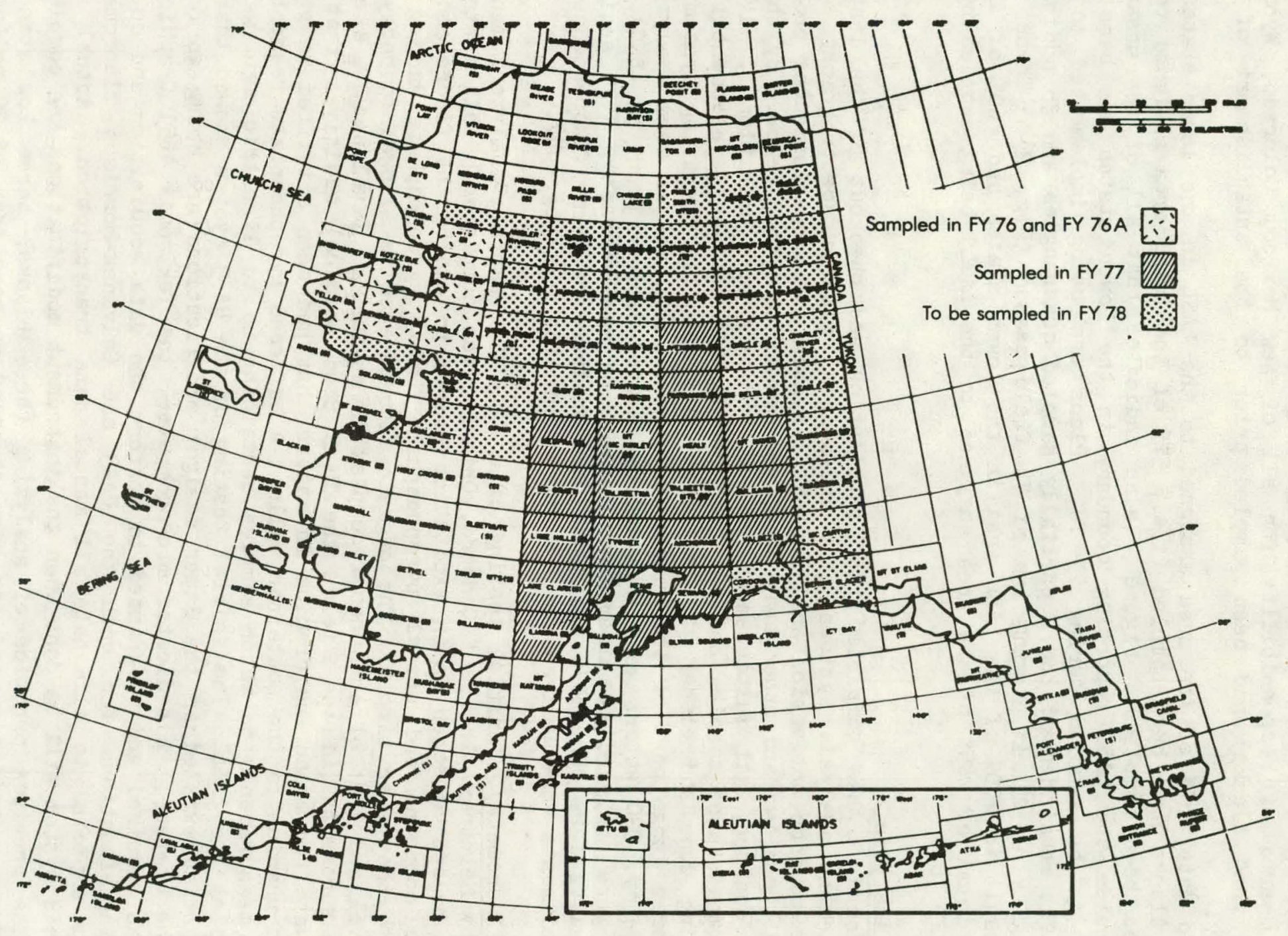

Fig. 2. Status of LASL HSSR reconnaissance sampling in Alaska (as of 31 March 1978). 
sampled. Major portions of 16 of the 66 lower-state and 4 Alaskan quadrangles had also been sampled. In addition, halves of eight and smaller portions of five quadrangles outside the LASL reporting boundary (but inside the LASL's original area of responsibility for all of New Mexico, Colorado, Wyoming, Montana, and Alaska) had been sampled prior to the establishment of that boundary.

To date, $67 \%$ of the area assigned to the LASL in the lower states and $27 \%$ of Alaska have been sampled (i.e., 57\% of the total area assigned to the LASL has been sampled). Figure 1 also indicates that all of the unsampled area inside the LASL reporting boundary in the lower states has been contracted to be sampled during FY 78. Plans are being implemented to also sample the remainder of the 4 partially sampled quadrangles and 35 additional quadrangles in Alaska during the FY 78 field season (Fig. 2). These plans will result in $100 \%$ of the LASL area in the lower states and $\checkmark 60 \%$ of Alaska (for a total of $585 \%$ of the area assigned to the LASL) being sampled by the end of FY 78 .

Sample Analysis

The LASL has completed the installation and checkout of the last two mulhielement analysis syotems: the ar'u-source emission spectrography system and the neutron activation analysis (NAA) system. The developmental progress made on these two and other analytical systems is described below. By the end of the quarter, all multielement analysis systems were operational, although no reconnaissance samples had yet been run by NAA because developmental work was being done and either the reactor or its computer operating system were down for a large part of the quarter. However, 6850 waters were analyzed by fluorometry, 930 waters were analyzed by delayed-neutron counting (DNC), 2440 waters were analyzed by plasma-source emission spectrography, 4170 sediments were analyzed by DNC, 6070 sediments were analyzed by $x$-ray fluorescence, and 2230 sediments were analyzed by arc-sourse emission spcctrography.

Fluorometry. Initial testing of a UA-3 fluorometric analyzer, manufactured by Scintrex, Inc., of Concord, Ontario, was completed. This instrument uses a pulsed nitrogen laser excitation source to excite the fluorescence of organic compound and uranyl pyrophosphate ions, pyrophosphate having been added to the water sample. The organic fluorescence is allowed to decay to a low level and that of the uranyl complex is measured. Developed as a system for measurements in the field, the UA-3 used chemical additives that were inadequate for measuring uranium in waters that had been acidified to prevent loss of uranium to the container walls. A buffered pyrophosphate reagent that allows measurements on water samples containing up to $1 \%$ nitric acid was developed at the LASL. The initial testing of the UA-3 system showed that some difficulties existed in the laser design; modifications are being worked out with the company. A dedicated microcomputer, the Tektronix 4051 Graphic Systcm, was acquired and programmed to perform the data acquisition and operator prompting functions for both the UA-3 and Galvanek-Morrison fluorometers. This is expected to eliminate all manual data transcription. Actual trials with this system will be done when the instrument modifications are completed.

The previous practice of analyzing three blanks, three low standards, three medium standards, and one high standard on each tray of 20 pellets has been provisionally modified. The blanks usually agree well; therefore, only two blanks will be used in the future. This space and another one formerly used for the extreme-high standard will be used for one additional sample to 
be analyzed in duplicate in each tray, a gain of $20 \%$ in the number of samples analyzed per tray.

During this quarter, an extensive review was made of the data on samples that were submitted. for DNC because the fluorometric values were greater than 10 parts per billion (ppb). In about $75 \%$ of these samples, the agreement in uranium value between duplicate aliquots was found to be satisfactory. The analysis of known samples in the range from 10 to $40 \mathrm{ppb}$ uranium indicates that accuracy is not impaired. As a result, concordant fluorometric values up to $40 \mathrm{ppb}$ will henceforth be reported and the samples will not be analyzed by DNC. Fluorometric data for several previously run areas were reexamined and the concordant values up to $40 \mathrm{ppb}$ were reported, greatly reducing the number of water samples waiting to be analyzed by DNC.

In the near future, a sample of a commercially mixed NaF-LiF flux material will be evaluated in comparison with the material mixed in this laboratory. If the larger batches of commercial mixture are more uniform, using them would save time and space in the water laboratory.

Plasma-Source Emission Spectrography. This system works very well for relatively pure water samples such as those from Alaska, and over 200 such samples can be run during a normal working day. However, some problems are caused by high magnesium and calcium concentrations. This is not a memory effect on the magnesium and calcium determinations, but rather, the problem is with a number of other elements that develop high background readings following the analysis of one of these samples. The cause is believed to be salt deposits, forming on the nebulizer tip, that change the nebulizer argon gas flow rate and thereby increase the background signal. Various solutions--from trying to find a better nebulizer, to cleaning the nebulizer tip after each sample with a small drop of water and/or, independently, to making the argon gas flow rate constant--are being explored.

To maximize the plasma source stability, four parameters must be rigidly controlled: 1) the power to the plasma, 2) the solution input rate, 3) the nebulizer argon gas flow rate, and 4) the coolant argon gas flow rate. Some electronic repairs, as well as a new matching network for the source, now give very stable power to the plasma. The solution input rate is now kept constant with a Gilson peristaltic pump. Automatic argon gas flow controllers are being ordered to stabilize the two argon gas flow rates.

Arc-Source Emission Spectrography. A drift of the spectrum along the spectrograph exit slits presently requires stopping each hour to readjust the spectrograph. Photomultiplier tubes and exit slits will be placed on the edges of two $\mathrm{Hg}$ lines, and the signals from these tubes will be used to readjust the spectrograph automatically during the time required to change electrodes between samples.

A desk-top calculator for this system was received and is being used to collect and calculate the sample results. A computer terminal is on order, which will allow writing results on cassette tapes that can then be used to relay the results to the LASL Central Computing Facility (CCF) data base. At the present time, all sample results must be read, checked, and entered on the CCF computer file by hand. This very time-consuming task greatly reduces the number of samples run per day.

Neutron Activation Analysis and Delayed-Neutron Counting. The combined multielement and uranium analysis pneumatic sample-handling system, involving 
one delayed-neutron counter and four $\mathrm{Ge}(\mathrm{Li}) \quad \gamma$-ray detectors, has been completed and is operational. During the quarter, multielement data acquisition programs for both short and long half-life activities have been put into operation, utilizing a PDP-11/20 computer. These programs write raw $\gamma$-ray data on magnetic tape for analysis at the CCF, using the OTTO analysis code. As many as 100 samples per day have been analyzed in this : way. This is an interim mode of operation, pending completion of modifications to the on-line $\gamma$-spectrum analysis code RAYGUN for the PDP-11/60 computer. The RAYGUN code, originally acquired from LASL's radiochemistry group, has required much more extensive changes for the HSSR application than had been anticipated. However, most of the problems have been solved, and by mid-April the analysis codes for both the short half-life and long half-life spectra should be operational. Preliminary results indicate that a complete spectral analysis, including peak identification and calculation of element concentrations, will take less than $60 \mathrm{~s}$.

Initially, there was concern that the Ge(Li) spectra'might have to be corrected for the time-dependent $\gamma$-ray hackground from the reactor. Thus, provision was made for the installation of massive lead shielding around the $\mathrm{Ge}(\mathrm{Li})$ detectors: Measurements now indicate that the overall background can essentially be ignored.

The pneumatic transfer system being used at the Omega West Reactor (OWR) for sediment samples is illustrated schematically in Fig. 3. A schematic of the control and data acquisition/analysis system for DNC and NAA is shown in F18. 4. These systems allow 200 sediment samples per day to be analyzed for 31 elements.

Data Management

Since January 1978, multielement data have been loaded into the appropriate HSSR data bases upon completion of the analyses. This has required the development of additional computer programs to store, retrieve, and display these data. Programs have also been written which allow uranium concentration histograins to be prepared for any subset of a quadrangle data base that can be described by latitude and longitude boundaries.

Data from approximately 12000 field data sheets, 13000 uranium analyses, and 1500 multielement analyses were loaded into data bases this quarter. Currently there are 67 active HSSR data bases and approximately 50 active computer programs to manipulate these data.

Reporting

The LASL, through DOE GJO, open filed the following four HSSR-related reports during the quarter:

GJBX-21(78) Hydrogeochemical and Stream Sediment Reconnaissanse nf the National Uranium Resource Evaluation program, AprilJune 1977, the Rocky Mountain states of New Mexico, Colorado, Wyoming, and Montana and the state of Alaska, by D. E. Broxton and H. P. Nunes, $28 \mathrm{p}$.

GJBX-22(78) Data management and handing for the Hydrogeochemical and Stream Sediment Reconnaissance program at the Los Alamos Scientific Laboratory, by J. Cheadle III, 3 p. 


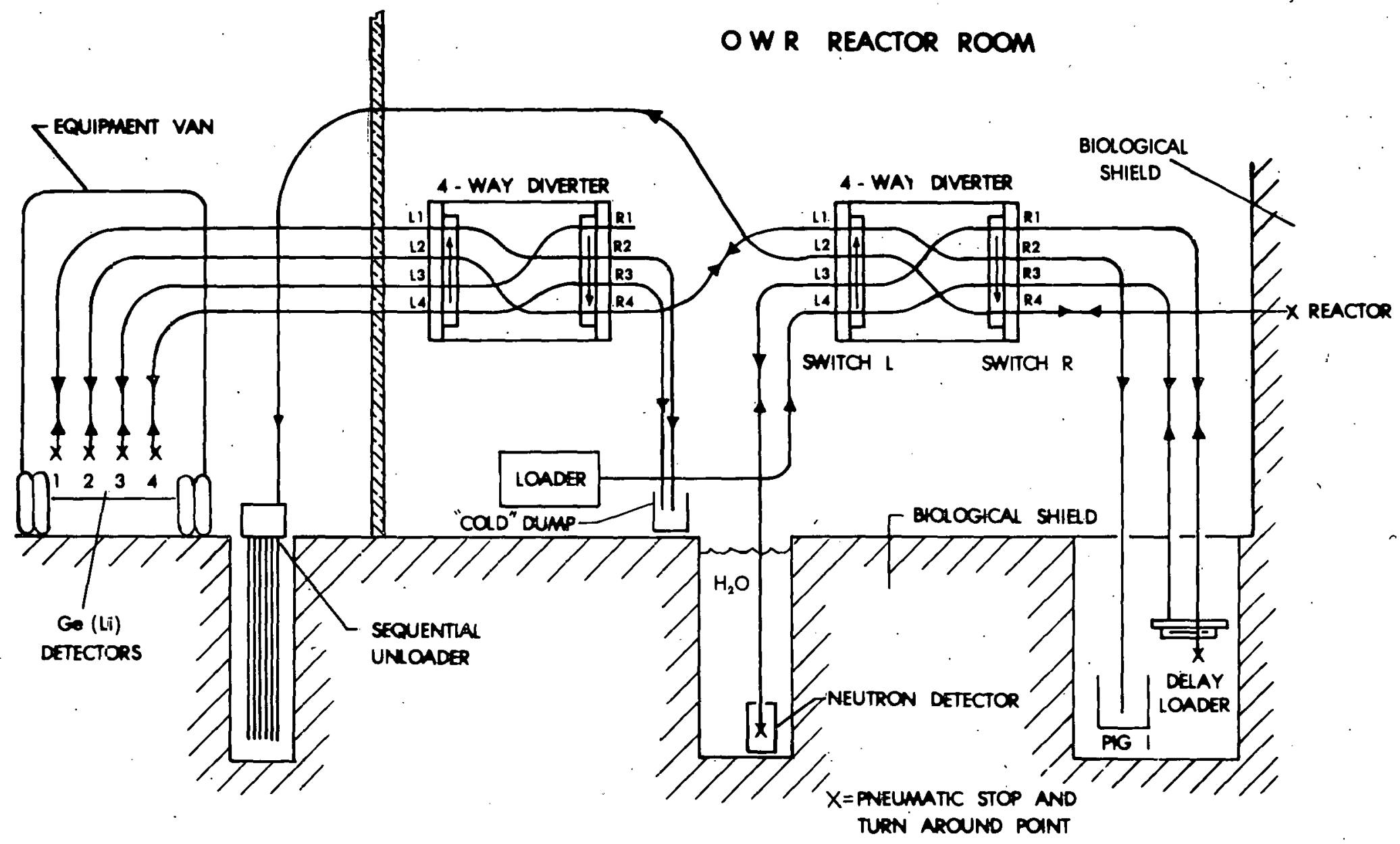

Fig. 3. LASL OWR pneumatic transfer system schematic. 


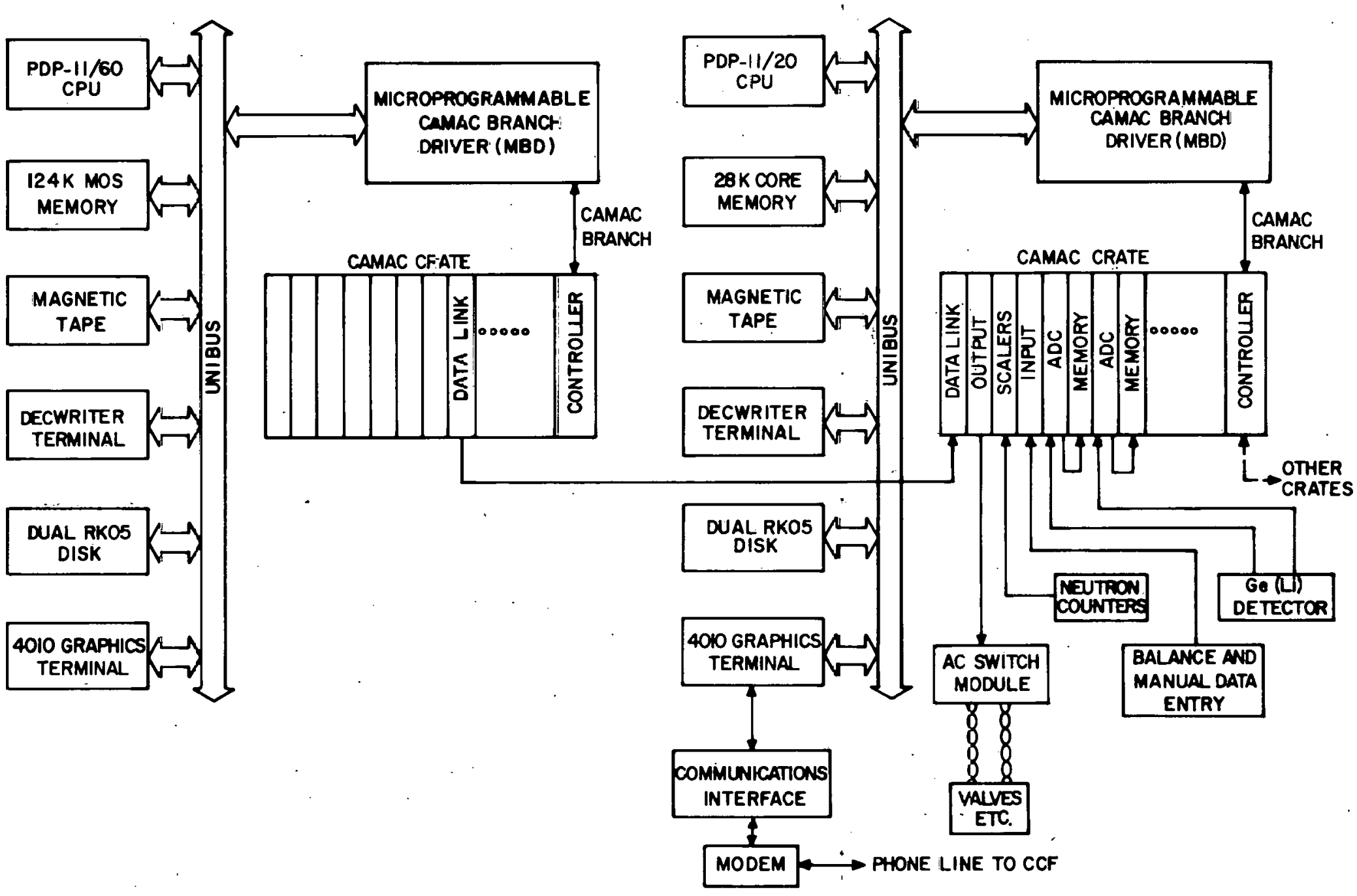

Fig. 4. Control and data acquisitio /analysis system schemctic for LASL DNC and NAA. 
GJBX-27(78) Hydrogeochemical and Stream Sediment Reconnaissance of the National Uranium Resource Evaluation program, JulySeptember 1977, the Rocky Mountain states of New Mexico, Colorado, Wyoming, and Montana and the state of Alaska, by $\mathrm{H}$. P. Nunes and T. A. Weaver, $14 \mathrm{p}$.

GJBX-28(78) Uranium hydrogeochemical and stream sediment reconnaissance in southwestern Montana, by D. E. Broxton, $95 \mathrm{p}$.

A complete bibliography of LASL HSSR-related reports (both open filed and in progress) is given in the appendixes. Appendix A contains all pilot and reconnaissance data reports, Appendix B contains reports related to LASL HSSR analytical and data handling methodology, and Appendix C lists LASL HSSR progress reports. Figures 5 and 6 illustrate the areas for which reports containing reconnaissance sampling data have been open filed or are scheduled to be open filed within six months for the lower states and Alaska, respectively.

Meetings

Robert R. Sharp, Jr., the LASL HSSR Program Manager, attended an HSSR operations and technical policy meeting in Grand Junction, Colorado, on March 22-23, 1978.

Personnel

Group G-5, Geochemical Applications, has added the following staff members: Jack D. Purson (B.S. in geology), Richard G. Warren (M.S. in both geology and cosmochemistry), Sue I. Jacobsen (M.S. in geology), and Spencer S. Shannon, Jr. (Ph.D. in geology). Anthony T. Garcia (data analyst) and Maxine L. Sanchez (secretary) have also joined the group. At the present time, there are 14 staff members and 11 support persons in Group G-5.

\section{ANALYTICAL PROCEDURES}

The sections below describe briefly the analytical procedures presently being used for the multielement analyses of LASL HSSR samples. Since some samples from areas being presently reported were collected and analyzed for uranium as much as three years ago, and since there has been much evolution in the analytical procedures for elements other than uranium over the last six months, each LASL HSSR data report. will contain "boiler plate" (in the appendixes of each report) that accurately describes the analytical procedures used when the samples being reported were analyzed.

Uranium Determination in Water Samples by Fluorometry

Under normal procedures, the water-sample vial is vigorously shaken and duplicate $0.20-\mathrm{ml}$ aliquots of water are transferred to platinum dishes. The solutions are evaporated under heat lamps and a 0.4-g pellet of 2\% LiF-98\% NaF flux is added to each dish. The pellets are dried under heat lamps, then fused over special propane burners. After each pellet/sample cools, it is excited with ultraviolet radiation in the fluorometer and the fluorescence is read and recorded. The uranium concentrations are determined by using a computer routine which compares the fluorescence from each pellet with those from other pellets, run at the same time, containing uranium-standard solutions and blanks. The uranium concentration of the sample is then the average obtained 


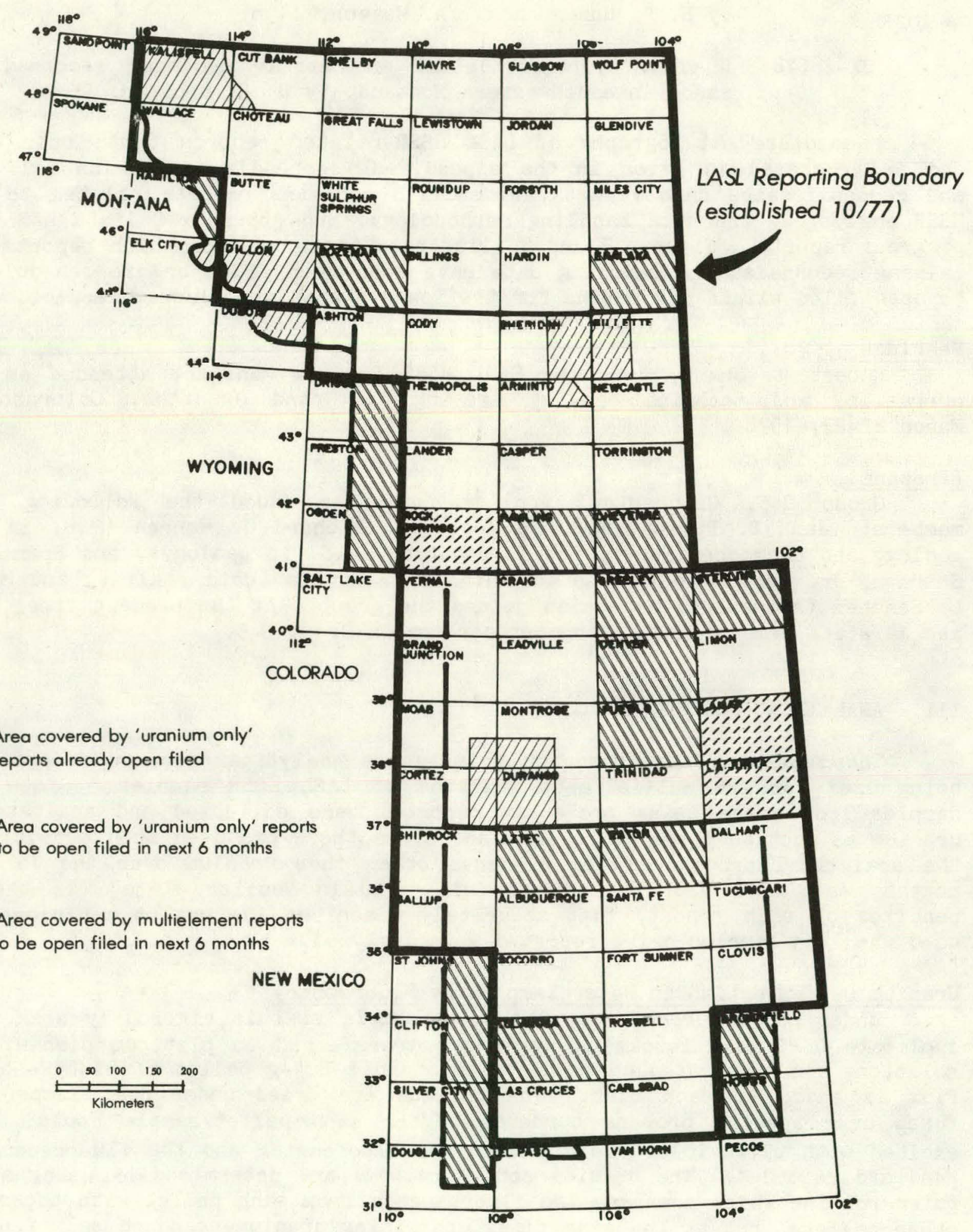

Fig. 5. LASL reconnaissance report status for the lower states (as of 31 March 1978). 


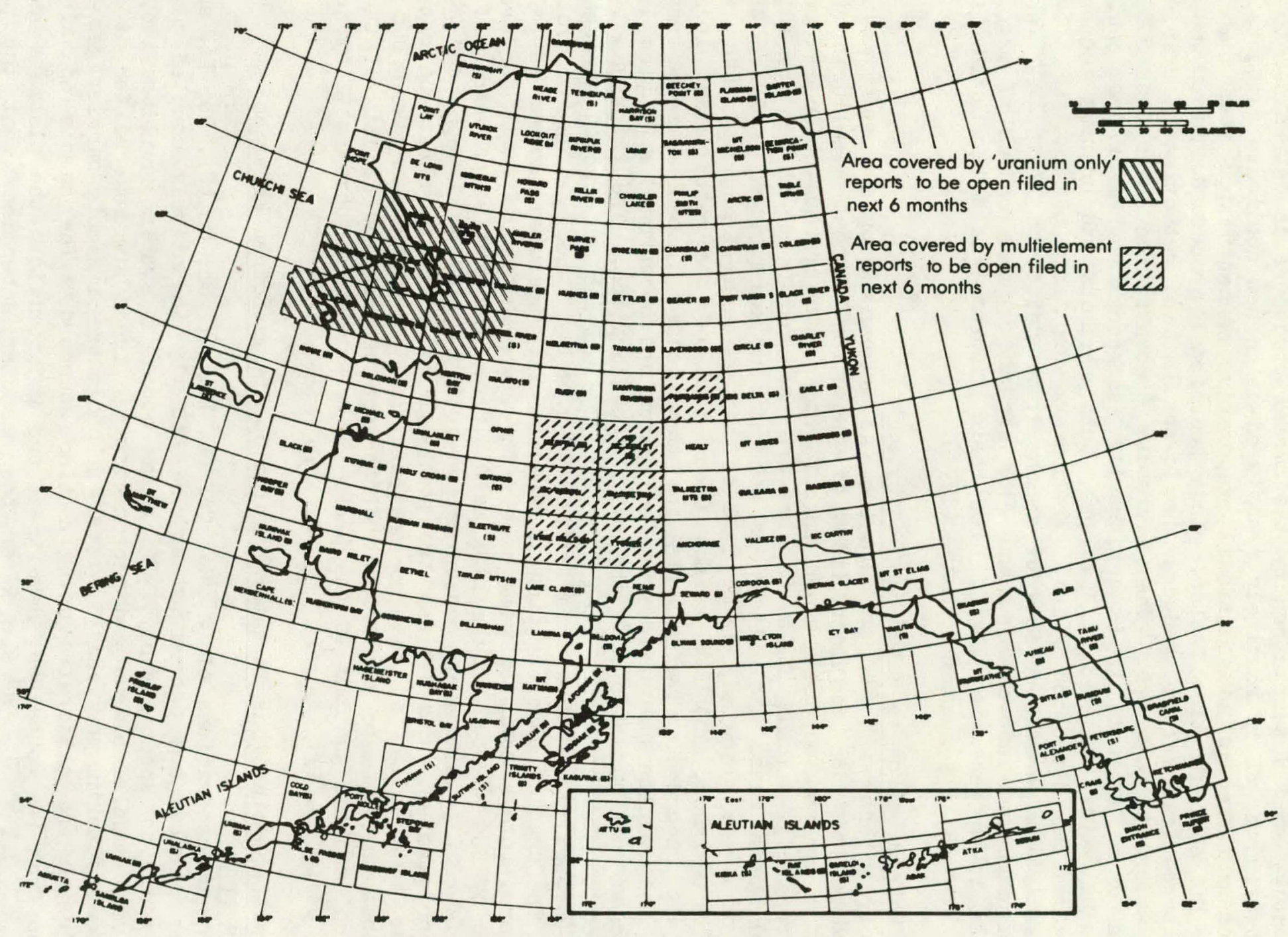

Fig. 6. LASL reconnaissance report status for Alaska (as of 31 March 1978). 
from the duplicate aliquots. The lower limit of detection for each aliquot by the normal procedure is $0.2 \mathrm{ppb}$; however, in areas at high latitudes (such as those in Alaska) many samples have uranium concentrations below this value. Consequently, when a sample run by the normal procedure is determined to have $<0.2 \mathrm{ppb}$ uranium, it is routinely reanalyzed using new duplicate aliquots that have been put through an additional evaporative concentration step that provides a $10 \mathrm{X}$ concentration factor. This additional procedure, using the same basic fluorometric method, reduces the lower limit of detection of uranium in natural waters to $0.02 \mathrm{ppb}$. When a uranium concentration lower than $0.02 \mathrm{ppb}$ is found in an aliquot, it is arbitrarily assigned a value of $0.01 \mathrm{ppb}$. If the uranium value reported is $0.01 \mathrm{ppb}$, both aliquots had uranium concentrations below the detection limit. Whether concentrated or not, the fluorometric analytical precision is $\checkmark 30 \%$ at the lower detection limit, $\checkmark 20 \%$ at one order of magnitude above this, and $s 10 \%$ at two or more orders of magnitude above the lower detection limit. The basic fluorometric method used is described in detail by Hues and others (1977).

Uranium Determination in Water Samples by DNC

Only waters with $>40 \mathrm{ppb}$ uranium (as determined by fluorometry at the LASL, where this is the upper limit of detection without recalibritinn) or those with impurities that cause interference with uranium-induced fluorescence are analyzed using DNC. Samples are received in 41-ml reactor rabbits or 25-ml vials (used exclusively in some of the early work) and are transferred to clean, labeled, 4l-ml rabbits before being analyzed. Each water sample is weighed, and its weight (less that of the rabbit) and location number are recorded. The rabbits are then loaded into 25-sample transfer clips. The reactor pneumatic transfer system and background radiation levels are checked and four standards are run for calibration. The transfer clip is installed on the pneumatic feed line and the samples are cycled through the system (typically, a 60-s irradiation, 30-s delay, and 60-s count cycle is used). The uranium concentration is automatically measured, converted to ppb, and entered into a computer data base. The lower detection limit for uranium in water by DNC as used at the LASL is $0.5 \mathrm{ppb}$. The statistical error of this method is $\backsim 20 \%$ at a uranium concentration of $1 \mathrm{ppb}$, $\backsim \kappa \%$ at $10 \mathrm{ppb}$, and $\wedge / 1 \%$ at $40 \mathrm{ppb}$ or greater. Statistical treatments of uranium concentrations obtained from the same suites of samples analyzed both by fluorometry and DNC have shown that there is no significant difference between the results of the two analytical methods as used at the LASL. This analytical comparability is rechecked periodically.

Elemental Determinations in Water Samples by Plasma-Source Emission Spectrography

The concentrations of $\mathrm{Ca}, \mathrm{Co}, \mathrm{Cr}, \mathrm{Cu}, \mathrm{Fe}, \mathrm{Mg}, \mathrm{Mn}, \mathrm{Mo}, \mathrm{Ni}, \mathrm{Pb}, \mathrm{Ti}$, and $\mathrm{Zn}$ in water samples are determined at the LASL by inductively coupled plasmasource emission spectrography. To allow complete system cquilihration, the inductively coupled plasma and photomultiplier tubes are powered for at least $1 \mathrm{~h}$ prior to making any analyses. Argon coolant and sample carrier gas lines are adjusted and calibrated using a zinc standard. The sample solution is taken up from its container, nebulized, and injected into the plasma source at a rate of $9.2 \times 10^{-9} \mathrm{~m} / \mathrm{s}$. After the computer determines that the photomultiplier tubes have stabilized, a 15-s exposure of the resultant spectrum is made on a direct-reading spectrograph. The resulting signals are read directly into a computer, and converted automatically to give the elemental 
concentrations. Corrections for interfering elements are made simultaneously by computer. When high (off-scale) results are obtained, the computer calls for the insertion of a filter between the plasma source and the spectrograph, repeats the readings, and then converts and stores the corrected elemental concentrations. The lower analytical detection limits generally achieved are (In ppb): Ca (20), Co (55), Cr (25), Cu (4), Fe (25), Mg (2), Mn (3), Mo (25), $\mathrm{Ni}(25), \mathrm{Pb}(200), \mathrm{Ti}(4)$, and $\mathrm{Zn}(50)$. However, when one or more interfering elements are present in especially high concentrations in a sample, the lower detection limit for one or more elements may shift to a higher value. Analytical precision for the elements as determined in water by this method is $\backsim 50 \%$ at the lower detection limit, improving to $\checkmark 10 \%$ one order of magnitude above the lower detection limit and to $<5 \%$ two orders of magnitude above the detection limit.

Uranium Determination in Sediment Samples by DNC

All sediment samples are analyzed for total uranium by DNC. A split of each sample (dried and sieved to -100 mesh) is transferred to a clean 4-ml rabbit, weighed (less the tare), and its weight recorded along with the appropriate location number. These rabbits are then loaded into 50-sample transfer clips. The reactor pneumatic transfer system and background radiation levels are checked, and standards are run for calibration. The transfer clip is installed and the samples are cycled through the system (typically, a 20-s irradiation, 10-s delay, and 20-s count cycle is used). The uranium concentration is automatically measured, converted to parts per mililion ( $\mathrm{ppm}$ ), and entered into the data base. The lower limit of detection of this method is $0.5 \mathrm{ppb}$ (not $\mathrm{ppm}$ ) uranium, below the range of uranium concentrations in natural sediment samples. Above the $1 \mathrm{ppm}$ level, the uranium values in sediment measured by DNC at the LASL have a one-sigma error of less than 4\%. The specially designed delayed-neutron detectors, built by the LASL and used for these analyses, are described by Balestrini and others (1976).

\section{Elemental Determinations in Sediment Samples by Energy Dispersive X-Ray}

\section{Fluorescence}

A computer-controlled energy-dispersive $x$-ray fluorescence system is used to determine $\mathrm{Ag}, \mathrm{BI}, \mathrm{Cd}, \mathrm{Cu}, \mathrm{Nb}, \mathrm{Ni}, \mathrm{Pb}, \mathrm{Sn}$, and $\mathrm{W}$ in sediments. The system consists of an automatic 20-position sample changer, a silicon lithiumdrifted detector, a pulsed molybdenum transmission-target $x$-ray tube, a multichannel analyzer, and a minicomputer. The sediment samples are prepared for analysis by grinding $6 \mathrm{~g}$ of each minus 100 -mesh sediment sample to a minus 325-mesh powder. A computer program positions the 6-g samples in the $x$-ray beam, unfolds overlapping peaks, determines peak intensities for each element, and calculates the ratio of the intensity of each peak to that of the molybdenum $\mathbf{K}_{x}$ Compton peak. Concentrations of each element are then calculated using equations obtained by analyzing prepared standards. Detection limits are: $5 \mathrm{ppm}$ for $\mathrm{Ag}, \mathrm{Bi}, \mathrm{Cd}$, and $\mathrm{Pb} ; 10 \mathrm{ppm}$ for $\mathrm{Cu}$ and $\mathrm{Sn} ; 15 \mathrm{ppm}$ for $\mathrm{Ni}$ and $\mathrm{W}$; and $20 \mathrm{ppm}$ for $\mathrm{Nb}$. The relative standard deviation is $10 \%$ or less at the $100-\mathrm{ppm}$ level and $20 \%$ or less at the $20-\mathrm{ppm}$ level. Details of the method and equipment used are described by Hansel and Martell (1977).

Elemental Determinations in Sediment Samples by Arc-Source Emission Spectrography

A 7.5-mg portion of the minus 325-mesh sample that has already been analyzed by $x$-ray fluorescence is mixed with $7.5 \mathrm{mg}$ of a buffer consisting of 
one part graphite and one part $\mathrm{SiO}_{2}$. The sample/buffer mixture is placed into a graphite electrode that is used as the anode of a de arc having a short circuit current of 17A. A 60-s exposure of the resulting spectrum is made on a direct-reading spectrograph. Photomultiplier tubes are used to measure the second order 313.0-nm line of Be, the first order 670.7- and 610.3-nm lines of $\mathrm{Li}$, the background spectra near these lines, and the 327.6-nm line of $V$. The $670.7-\mathrm{nm} \mathrm{Li}$ line is used for $\mathrm{Li}$ concentrations up to $30 \mathrm{ppm}$, while the $610.3-\mathrm{nm}$ line of $\mathrm{Li}$ is used for concentrations above $30 \mathrm{ppm}$. The $\mathrm{V}$ line is used to correct the $\mathrm{Be}$ value when $\mathrm{V}$ is above $1000 \mathrm{ppm}$. The signals from the photomultiplier tubes are read by a digital voltmeter and are processed by a desktop calculator. The results are simultaneously printed on paper and written on cassette tape for later transmission to a computer data file. The elemental concentrations of $\mathrm{Be}$ and $\mathrm{Li}$ are determined from the spectra, based on the results of previously run calibration standards. The lower detection limit for both elements is $1 \mathrm{ppm}$; precision at the lower detection limit is $\backsim 50 \%$ for both and improves to $\Omega 25 \%$ at one order of magnitude above the lower limit.

Elemental Determinations in Sediment Samples by NAA

Inediateiy upon completion of the uranium analysis of sediment samples by DNC, the same 4-ml sediment splits are entered into the NAn sequcnce. The conoentrations of 31 additional elements are determined by this procedure. The full DNC/NAA timing sequence used at the LASL for each sediment sample is: 20-s irradiation, 10-s delay, 20-min delay, 500-s $\gamma$-ray count, 96-s re-irradiation, 14-day delay, and finally a 1000-s $\gamma$-ray count. The $\gamma$-ray counting is done by lead-shielded $\mathrm{Ge}(\mathrm{LI})$ detectors; the 4096-channel $\gamma$-ray data are recorded and subsequently analyzed for each individual element by computer. The data for each sample are automatically printed out along with the statistical error associated with the concentration determined for each particular element in that sample. The lower detection limits for the various elements are the values for those elements at which the statistical counting error for each approaches 50\%. Current "typical" lower detection limits for the elements determined by NAA are reported in Nunes and Weaver (1978); however, the actual detection limit for an element depends upon the composition of the sample, and this limit may be higher or lower than the "typical" value. At concentration values one order of magnitude above the lower detection limits, the relative errors are generally less than $10 \%$. 


\section{REFERENCES}

Balestrini, S. J., Balagna, J. P., and Menlove, H. 0., 1976, Two specialized delayed-neutron detector designs for assays of fissionable elements in water and sediment samples; Nuclear Instruments and Methods, v. 136, pp. 521-524.

Hansel, J. M., and Martell, C. J., 1977, Automated energy dispersive X-ray determination of trace elements in stream sediments, US ERDA, Open-File Report GJBX-52(77), Grand Junction, $C 0,8$ p.

Hues, A. D., Henicksman, A. L., Ashley, W. H., and Romero, D., 1977, The fluorometric determination of uranium in natural waters at the Los Alamos Scientific Laboratory, Los Alamos; NM, US ERDA, Open-File Report GJBX-24(77), Grand Junction, $\infty, 11 \mathrm{p}$.

Morris, W. A., Bunker, M. E., and Steinhaus, D. W., 1978, Hydrogeochemical and Stream Sediment Reconnaissance of the National Uranium Resource Evaluation program, October-December 1977, the Rocky Mountain states of New Mexico, Colorado, Wyoming, and Montana and the state of Alaska, US DOE, Open-File Report GJBX-77(78), Grand Junction, $C O, 10 \mathrm{p}$.

Nunes, H. P., and Weaver, T. A., 1978, Hydrogeochemical and Stream Sediment Reconnaissance of the National Uranium Resource Evaluation program, JulySeptember 1977, the Rocky Mountain states of New Mexico, Colorado, Wyoming, and Montana and the state of Alaska, US DOE, Open-File Report GJBX-27(78), Grand Junction, $\mathrm{CO}, 14 \mathrm{p}$. 


\section{THIS PAGE}

\section{WAS INTENTIONALLY \\ LEFT BLANK}




\begin{abstract}
APPENDIX A
HYDROGEOCHEMICAL AND STREAM SEDIMENT RECONNAISSANCE DATA REPORTS PREPARED BY LASL FOR OPEN FILING

BY THE US DOE, GRAND JUNCTION OFFICE
\end{abstract}


APPENDIX A

HYDROGEOCHEMICAL AND STREAM SEDIMENT RECONNAISSANCE DATA REPORTS

PREPARED BY LASL FOR OPEN FILING

BY THE US DOE, GRAND JUNCTION OFFICE

GJBX $-35(76)$

GJBX-21(77)

GJBX-22( 77 )

GJBX-31(77)

GJBX-39(77)

GJBX-48(77)

GJBX-63(77)

GJBX-94 ( 77)

GJBX-28(78)

(In press)

(In press)

(In press)
Uranium concentrations in natural waters, South Park, Colorado, R. R. Sharp, Jr., and P. L. Aamodt, LA-6400-MS, 49 p.

Uranium hydrogeochemical and stream sediment pilot survey of the Estancia Valley--Bernal11lo, Santa Fe, San Miguel, and Torrance Counties, New Mexico, C. E. Olsen, LA-6650-MS, 32 p. plus App.

Uranium hydrogeochemlcal and stream sediment reconnaissance In the San Juan Mountains, southwestern Colorado, J. C. Maxwe 11, LA =6651-MS, $104 \mathrm{p}$.

Uranium concentrations in lake and stream waters and sediments from selected sites in the Susitnd River. Rasin, Aliska, D. E. H111, LA-6730-MS, 31 p.

Raw data report of elemental analyses from hydrogeochemical and stream sediment samples taken near Sterling and Fort Morgan, northeastern Colorado, December 1976 and January 1977, J. C. Maxwell, LA-6740-MS, 27 p.

Uranium hydrogeochemlcal and stream sediment reconnaissance in Lincoln and Flathead Counties, northwest Montana, P. L. Aamodt, LA-6652-MS, 41 p. + App.

Results of elemental analyses of water and waterborne sediment samples from the proposed Cape Rrusenstern National Monument, Alaska, R. R. Sharp, Jr., LA-6945-MS, 28 p.

Uranium hydrogeochemlcal and stream sediment reconnaissance of the northern part of the Powder River Basin, Wyoming, W. A. Morris, LA-6654-MS, 80 p.

Uranium hydrogeochemical and stream sediment reconnaissance in southwestern Montana, D. E. Broxton, LA-6981, 95 p.

Uranium hydrogeochemical and stream sediment reconnaissance of the Ekalaka NTMS quadranglc, Montana, D. 3. Chaney and S. L. Bolivar, LA-7069-MS, 71 D.

Uranium hydrogeochemical and stream sediment pilot study of the Boulder Batholith, Montana, P. L. Aamodt, LA-7176-MS, $118 \mathrm{p}$.

Uranium hydrogeochemical and stream sediment reconnaissance of the Denver and Greeley NTMS quadrangles, Colorado, S. L. Bolivar, D. E. Broxton, and C. E. Olsen, LA-7177-MS, 138 p. 
(In press)

Uranium hydrogeochemical and stream sediment reconnaissance data release for the Montana portion of the Hamilton, Montana/Idaho, NTMS quadrangle, P. L. Aamodt, LA-7178-MS, 45 p.

(In press) Uranium hydrogeochemical and stream sediment reconnaissance data release of the Douglas, Silver City, Clifton, and Saint Johns NTMS quadrangles, Arizona/New Mexico, R. R. Sharp, Jr., W. A. Morris, and P. L. Aamodt, LA-7180-MS, 123 p.

(In press)

Uranium hydrogeochemical and stream sediment reconnaissance data release for the Wyoming portions of the Driggs, Preston, and Ogden NTMS quadrangles, D. E. Broxton and H. P. Nunes, LA-7181-MS, $93 \mathrm{p}$.

(In preparation) Uranium hydrogeochemical and stream sediment reconnaissance data from the area of the Teller, Bendeleben, Candle, and Kateel River quadrangles, Seward Peninsula and vicinity, Alaska, R. R. Sharp, Jr., and D. E. Hill, LA-6844-MS.

(In preparation) Uranium hydrogeochemical and stream sediment reconnaissance data from the area of the Shishmaref, Kotzebue, Selawik, and Shungnak quadrangles, northern Seward Peninsula and vicinity, Alaska, R. G. Warren, D. E. Hill, and R. R. Sharp, Jr., LA-6845-MS.

(In preparation) Uranium hydrogeochemical and stream sediment reconnaissance data from the area of the Noatak and portions of the Baird Mountains and Ambler River quadrangles, Alaska, P. L. Aamodt, D. E. Hill, and R. R. Sharp, Jr., LA-6846-MS.

(In preparation) Uranium concentrations in stream waters and sediments from selected sites in the eastern Seward Peninsula, Koyukuk, and Charley River areas, and across south-central Alaska, R. R. Sharp, Jr., and D. E. Hill, LA-6649-MS.

(In preparation) Uranium hydrogeochemical and stream sediment reconnalssance of the Rawlins NTMS quadrangle, Wyoming, T. A. Weaver, W. A. Morris, and P. K. Trexler, LA-7179-MS.

(In preparation) Uranium hydrogeochemical and stream sediment reconnaissance data release for the New Mexico portions of the Hobbs and Brownfleld NTMS quadrangles, New Mexico/Texas, R. G. Warren and H. P. Nunes, LA-7182-MS.

(In preparation) Uranium hydrogeochemical and stream sediment reconnaissance of the Tularosa NTMS quadrangle, New Mexico, D. E. Broxton, LA-7217-MS.

(In preparation) Uranium hydrogeochemical and stream sediment reconnalssance of the Cheyenne NTMS quadrangle, Wyoming, P. R. Trexler, LA-7237-MS. 
(In preparation) Uranium hÿdrogeochemical and stream sediment reconnaissance of the Aztec NTMS quadrangle, New Mexico, S. L. Bolivar, LA-7238-MS.

(In preparation) Uranium hydrogeochemical and stream sediment reconnaissance data release for the sterling NTMS quadrangle, Colorado, H. P. Nunes, LA-7305-MS.

(In preparation) Uranium hydrogeochemical and stream sediment reconnaissance of the Pueblo NTMS quadrangle, Colorado, S. S. Shannon, Jr., LA-7341-MS.

(In preparation) Uranium hydrogeochemical and stream sediment reconnaissance of the Lamar NTMS quadrangle, Colorado (including concentrations of forty-three assoclated elements), L $\Lambda=7342-M S$.

(In preparation) Uranium hydrogeoohemical and stream sediment reconnaissance of the La Juild NTMS quadrangle, Colorado (including concentrations of forty-three associated elements), LA-7343-MS,

(In preparation) Uranium hydrogeochemical and stream sëdiment reconnaissance of the Raton NTMS quadrangle, New Mexico, T. L. Morgan and D. E. Broxton, LA-7344-MS.

(In preparation) Uranium hydrogeochemical and stream sediment reconnalssance of the Lime Hills and Tyonek NTMS quadrangles, Alaska (including concentrations of forty-three associated elements), LA-7348-MS.

(In preparation) Uranium hydrogeochemical and stream sediment reconnaissance data release for the Fairbanks NTMS quadrangle, Alaska (including concentrations of forty-three associated elements), LA-7349-MS.

(In preparation) Uranium hydrogeochemical and stream sediment reconnaissance of the McGrath and Talkeetna NTMS quadrangles, Alaska (including concentrations of forty-three associated elements), LA-7350-MS.

(In preparation) Uranium hydrogeochemical and stream sediment reconnaissance of the Medfra and Mt. McKinley NTMS quadrangles, Alaska (including concentrations of forty-three associated elements), LA-7351-MS.

(In preparation) Uranium hydrogeochemical and stream sediment reconnaissance of the Bozeman NTMS quadrangle, Montana, LA-7504-MS.

(In preparation) Uranium hydrogeochemical and stream sediment reconnaissance of the Rock Springs NTMS quadrangle, Wyoming (including concentrations of forty-three associated elements), LA-7543-MS. 


\begin{abstract}
APPENDIX B
HYDROGEOCHEMIICAL AND STREAM SEDIMENT RECONNAISSANCE PROGRAM-RELATED REPORTS PREPARED BY LASL FOR OPEN FILING

BY THE US DOE, GRAND JUNCTION OFFICE
\end{abstract}


HYDROGEOCHEMICAL AND STREAM SEDIMENT RECONNAISSANCE PROGRAM-RELATED REPORTS PREPARED BY LASL FOR OPEN FILING

BY THE US DOE, GRAND JUNCTION OFFICE

GJBX-24(77) The fluorometric determination of uranium in natural waters, A. D. Hues, A. L. Henicksman, W. H. Ashley, and D. Romero, LA-6683-MS, $11 \mathrm{p}$.

GJBX-32(77) Investigations of the Inductively coupled plasma source for analyziing NURE water samples at the Los Alamos Scientific Laboratory, C. T. Apel, T. M. Bieniewski; L. E. Cox, and D. W. Steinhaus, LA-6751-MS, $11 \mathrm{p}$.

GJBX-52(77) Automated energy-dispersive x-ray determination of trace elements in stream sediments, J. M. Hansel and C. J. Martell, LA-6869-MS, $8 \mathrm{p}$.

GJBX-54(77) Computer program for Universal Transverse Mercator map projection, J. Cheadle III, LA-6902-MS, 11 p.

GJBX-77(77) The LASL spproach to uranium geochemical reconnaissance, in Proceedings of Symposium on Hydrogeochemical and Stream-Sediment Reconnalssance for Uranium in the United States, R. R. Sharp, Jr., LA-UR77-1122, pp. 353-373.

GJBX-22(78) Data management and handling for the Hydrogeochemical and Stream Sediment Reconnaissance program at the Los Alamos Scientific Laboratory; J. M. Chcadlc, Jr.; LA-7128-MS, 3 p.

GJBX-68(78) Field procedures for the Uranium Hydrogeochemical and Stream Sediment Reconnaissance as used by the Los Alamos Scientific Laboratory, R. R. Sharp, Jr., and P. L. Aamodt, LA-7054-M, 64 p.

Hydrogeochemical and Stream Sediment Reconnaissance for uranium, P. L. Aamodt, Mini-Review LASL-77-34, 4 p. 


\section{APPENDIX C}

HYDROGEOCHEMICAL AND STREAM SEDIMENT RECONNAISSANCE QUARTERLY PROGRESS REPORTS PREPARED BY LASL FOR OPEN FILING

BY THE THE US DOE, GRAND JUNCTION OFFICE 
APPENDIX C

HYDROGEOCHEMICAL AND STREAM SEDIMENT RECONNAISSANCE QUARTERLY PROGRESS REPORTS PREPARED BY LASL FOR OPEN FILING

BY THE THE US DOE, GRAND JUNCTION OFFICE

GJBX-19(76) Hydrogeochemical and Stream Sediment Survey of the National Uranium Resource Evaluation program, April-June 1975, the Rocky Mountain states of New Mexico, Colorado, Wyoming, and Montana and the state of Alaska, R. R. Sharp, Jr., LA-6299-PR, 48 p.

GJBX-25(76) Hydrogeochemical and Stream Sediment Survey of the National Uranium Resource Evaluation program, July-September 1975, the Rocky Mountain states of New Mexico, Colorado, Wyoming, and Montana and the state of Alaska, R. R. Sharp, Jr., and W. A, Morris, LA-6319-PR, $47 \mathrm{p}$.

GJBX-38(76) Hydrogeochemical and Stream Sediment Survey of the National Uranium Resource Evaluation program, October-Lecember 19.75, the Rocky Mountain states of New Mexico, Colorado, Wyoming, and Montana and the state of Alaska, R. R. Sharp, Jr., and

P. L. Aamodt, LA-6346-PR, 86 p.

GJBX-39(76) Hydrogeochemical and Stream Sediment Survey of the National Uranium Resource Evaluation program, January-March 1976, the Rocky Mountain states of New Mexico, Colorado, Wyoming, and Montana and the state of Alaska, R. R. Sharp, Jr., W. A. Morris, and P. L. Aamodt, LA-6369-PR, 56. p.

GJBX-65(76) Hydrogeochemical and Stream Sediment Reconnaissance of the National Uranium Resource Evaluation program, April-June 1976, the Rocky Mountain states of New Mexico, Colorado, Wyoming, and Montana and the state of Alaska, W. A. Morris and P. L. Aamodt, LA-6519-PR, $25 \mathrm{p}$.

GJBX-12(77) Hydrogeochemical and Stream Sediment Reconnaissance of the National Uranium Resouroe Evaluation program, July-September 1976, the Rocky Mountain states of New Mexico, Colorado, Wyoming, and Montana and the state of Alaska, W. A. Morris, $L A-664 \mu-P R, 22 \mathrm{p}$.

GJBX-20(77) Hydrogeochemical and Stream Sediment Reconnaissance of the National Uranium Resource Evaluation program, OctoberDecember 197.6, the Rocky Mountain states of New Mexico, Colorado, Wyoming, and Montana and the state of Alaska, P. L. Aamodt, J. M. Hansel, Jr., M. M. Minor, and R. J. Beckman, LA-6708-PR, $27 \mathrm{p}$. 
GJBX-51(77) Hydrogeochemical and Stream Sediment Reconnalssance of the National Uranium Resource Evaluation program, January-March 1977, the Rocky Mountain states of New Mexico, Colorado, Wyoming, and Montana and the state of Alaska, P. L. Aamodt, G. R. Waterbury, and M. E. Bunker, LA-6831-PR, 15 p.

GJBX-21(78) Hydrogeochemical and Stream Sediment Reconnaissance of the National Uranium Resource Evaluation program, April-June 1977, the Rocky Mountain states of New Mexico, Colorado, Wyoming, and Montana and the state of Alaska, D. E. Broxton and H. P. Nunes, LA-6992-PR, $28 \mathrm{p}$.

GJBX-27(78). Hydrogeochemical and Stream Sediment Reconnaissance of the National Uranium Resource Evaluation program, July-September 1977, the Rocky Mountain states of New Mexico, Colorado, Wyoming, and Montana and the state of Alaska, 'H. P. Nunes and I. A. Weaver, LA-6993-PR, $14 \mathrm{p}$.

(In press) Hydrogeochemical and Stream Sediment Reconnaissance of the National Uranium Resouroo Evaluation program; Detoher= December 1977, the Rocky Mountain states of New Mexico, Colorado, Wyoming, and Montana and the state of Alaska, W. A. Morr 1s, M. E. Bunker, and D. W. Steinhaus, LA-7175-PR, $10 \mathrm{p}$. 
1 - W. R. Volgt, Jr., Director

Division of Uranium Resources and Enrichment. Resource Applications, US DOE HDQTRS Washington, DC 20545

1 - R: D. Nininger, Asst. D1r., Raw Materials Division of Uranlum Resources and Enrichment Resource Applications, US DOE HDQTRS Washington, DC 20545

1 - R. J. Wright Division of Uranium Resources and Enrichment Resource Applications, US DOE HDQTRS Washington, DC 20545

5 - B. Borryer, Act1ng Manager US DOE, Grand Junction Office P. 0. Box 2567 Grand Junction, CO 81501

1 - D. E. Livingston Bendix Field Engineering Corporation P. O. Box 1569 Grand Junction, co 81501

1 - N. Stetson, Manager US DOE, Savannah RIver Operations office P. O. Box A Aiken, SC 29801

1 - C. H. Ice, Director E. I. du Pont de Nemours \& Company Savannah River Laboratory Aiken, SC 2980
2 - E. I. Baucom Analytical Chemistry Division E. I. du Pont de Nemours \& Company Savannah River Laboratory

A1ken, SC 29801

1 - M. A. Boyd, Development Division US DOE, Oak Ridge Operations Office P. O. Box E Oak Ridge, TN 37830

1 - J. C. White, Manager Technical Service, Y-12 Plant Unton Carbide Corporation P. O. Box Y Oak Ridge, TN 37830

2 - J. W. Arendt, Project Manager Uranium Resource Evaluation Union Carbide Corporation ORGDP R-25

P. O. Box P Oak Ridge, TN 37830

2- T. W. Offield, Chief. Branch of Uranium-Thorium Resources US Geological Survey Denver Federal Center, Bldg. 25 Denver, CO 80225

1 - A. P. D'Silva Room 9, Spedding Hall Ames Laboratory Iowa State University Ames, Iowa 50011

\section{INTERNAL DISTRIBUTION}

1 - D. K. Nowlin, D1r., Special Projects Division, US DOE ALOO

1 - R. F. Taschek/S. J. Merlan, ADR

1 - R. R. Brownlee/L. S. Germain, G-DO

1 - R. D. Baker, CMB-DO

1 - G. R. Haterbury, $O B-1$

1 - H. T. Motz, P-DO

1 - M. E. Bunker M. M. Minor, P-2

1 - J. M. Hilliams, S-DO

1 - R. A. Waller/R. R. Zelgler, $S-1$

1 - J. C. Hopkins/R. H. Campbell, J-DO

1 - G. A. Cowan, CNC-DO

1 - J. E. Satt1zahn/J. P. Balagna, CNC-11

1 - Ma1l and Records, ISD-5

1 - G-5 F1108 